\title{
Effect of Optimal Mixing Ratio of Dendropanax, Sea Salt, and Other Extracts on the Alleviation of Hair Loss Symptoms
}

Yeon-Je Cho, Yun-Hee Choi, Byung-Loc Kim, Min-Hee Han, Hak-Sung Lee, Yong-Gi Jeong*

Center of Natural Resources Research, Jeonnam Bioindustry Foundation, Jangheung-gun, Jeollanam-do, Korea

*Corresponding author: Yong-Gi Jeong, Center of Natural Resources Research, Jeonnam Bioindustry Foundation, 288 Woodland-gil, Anyang-myeon, Jangheunggun, Jeollanam-do 59338, Korea

Tel.: +82618602630

Fax: +82618647105

Email: go6115@nate.com

Received August 20, 2021

Revised October 19, 2021

Accepted November 22, 2021

Published December 30, 2021

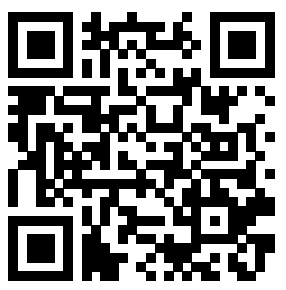

\begin{abstract}
Purpose: This study was conducted to select the optimal mixing ratio (OMR) of extracts including Dendropanax, sea salt, and others from Jeollanam-do and to develop functional cosmetics that can help alleviate hair loss symptoms. Methods: Our research team determined the OMR through cytotoxicity and cell proliferation tests, and confirmed the anti-inflammatory and anti-microbial effects of the final selected OMR. Results: The cytotoxicity was low when the OMR was 0.1:1:5:1, but cell proliferation was high, and anti-inflammatory activity effectively inhibited the expression of IL-6 and iNOS. The anti-microbial activity also had an effect on Pseudomonas aeruginosa and Staphylococcus aureus. Conclusion: This study selected OMR (1:0.1:5:1) to develop functional cosmetics that can help alleviate hair loss symptoms. The final selection of OMR confirmed low cytotoxicity, high cell proliferation, inhibition of expression of IL-6 and iNOS, and anti-microbial activity. Therefore, it is expected to serve as a functional cosmetic that can help alleviate hair loss symptoms in the future.
\end{abstract}

Keywords: Optimal mixing ratio, Dendropanax, Sea salt, Hair loss symptoms, Functional cosmetics

\section{Introduction}

탈모는 정상적으로 모발이 존재해야 할 부위에 모발이 없는 상태 를 말하며, 생명에 지장은 없지만 삶의 질을 떨어뜨리는 현대인의 대 표적인 질환이다. 현재 미용에 대한 관심이 높아지면서 탈모 치료 에 대한 요구가 증대됨에 따라 다양한 치료방법이 시도되고 있다. 대표적으로는 미녹시딜이 포함된 외용제와 피나스테리드인 내복약 등이 치료제로 사용되고 있으나, 두피 건조, 가려움, 피부 자극, 성 욕 감퇴, 발기 부전 등의 부작용이 수반되고 있다(Pinnell \& Murad, 1987; Jang et al., 2015; Kim et al., 2019a; Kim \& Park, 2020).

최근 천연 식물 추출물로부터 부작용이 없고 모발성장 및 재생에 효과적인 연구가 추진되고 있다. 특히, 황칠 열수 추출물에서 분리 한 베타-시토스테롤( $\beta$-sitosterol)이 다양한 피부개선 효과와 탈모방 지에 효과가 있는 것으로 보고되었다(Lee et al., 2015a). 또한, 신안 비금도산 천일염은 높은 미네랄을 함유하고 있으며, 피부의 수분보 호, 피부미용 및 두피케어 등에 도움을 줄 수 있는 것으로 알려져 있
다(Lee et al., 2014; Kim et al., 2015). 그 외에도 면역력 강화, 천 식 완화, 심혈관 보호, 근육통 완화, 소화 촉진 및 우울증 해소 등 다 양한 효능이 입증되고 있다. 또한 시금치와 다시마는 항산화 활성과 미네랄 성분이 함유되어 두피 건강에 도움을 준다고 알려져 있다(Lee et al., 2015b; Jung et al., 2019).

본 연구에 앞서 황칠, 천일염, 시금치 및 다시마 등의 열수 추출물, $30 \%$ 주정 추출물과 $60 \%$ 주정 추출물에서 이미 세포독성, 세포증식 율, 항염증 및 항균활성 등 안전성 및 유효성을 확인한 바 있다(Choi et al., 2021). 특히, 열수 추출물들은 주정 추출물들에 비해 높은 안 전성과 최적 농도 범위내에서 세포증식율, 항염증 등 탈모 증상 완화 에 도움을 줄 수 있는 화장품 소재로 그 기능성을 확인하였다.

따라서, 본 연구에서는 전남산 황칠, 천일염, 시금치 및 다시마 등 의 추출물을 일정비율 배합하여 탈모증상 완화에 도움을 줄 수 있는 최적 배합비율(optimal mixing ratio, OMR)을 선정함으로써 향후 기 능성 화장품 원료로 사용하기 위한 안전성 및 유효성을 검증하고자 한다. 


\section{Materials \& Methods}

\section{1. 시료 준비}

본 연구의 원재료인 황칠(Dendropanax)은 전남 장흥산으로 그 잎 과 잔가지를 세척 후, 실내에서 자연 건조하여 사용하였으며, 신안 비금도산 천일염(sea salt)은 탈수 후, 가는 입자로 가공 및 멸균하여 사용하였다. 또한 신안 비금도산 시금치(spinach)는 구입하여 세척 후 $50^{\circ} \mathrm{C}, 12 \mathrm{~h}$ 열풍 건조하여 사용하였고, 완도산 건다시마(kelp)도 구입하여 세척 및 염분 제거 후 $50^{\circ} \mathrm{C}, 6 \mathrm{~h}$ 열풍 건조하여 사용하였 다. 준비된 황칠, 천일염, 시금치 및 다시마 등은 시험에 사용할 배합 비율별로 제조하기 위하여 각 원재료와 물을 $1: 10$ 의 비율로 $100^{\circ} \mathrm{C}$, $8 \mathrm{~h}$ 동안 열수 추출 후 $72 \mathrm{~h}$ 동결 건조하였다. 동결 건조물 각 $1 \mathrm{~g}$ 을 $10 \mathrm{~mL}$ 멸균수로 녹여 $0.1 \mathrm{~g} / \mathrm{mL}$ 농도의 stock을 만들고, 시료로 사용하였으며, 이때, 사용된 최적 배합비율은 중량비를 적용하였다 (Kim et al., 2018; Choi et al., 2021).

\section{2. 세포배양}

세포독성과 세포증식율 시험에 사용한 모유두세포(human follicle dermal papilla cell, HFDPC; Genophile, Korea)는 90\% Dulbecco's modified eagle's medium (DMEM; Gibco, USA), 10\% fetal bovine serum (FBS; Millipore, USA) 및 1\% penicillin and streptomycin antibiotics $\left(\mathrm{P} / \mathrm{S}\right.$; Gibco, USA)를 첨가한 배지에 $37^{\circ} \mathrm{C}, 5 \% \mathrm{CO}_{2}$ 조건 하에서 배양하였다. 또한 항염증 시험을 위한 Raw 264.7 세포(Korea cell line bank, KCLB; Korea)도 마찬가지로 90\% DMEM, 10\% $\mathrm{FBS}, 1 \% \mathrm{P} / \mathrm{S}$ 를 첨가한 배지에서 $37^{\circ} \mathrm{C}, 5 \% \mathrm{CO}_{2}$ 조건의 동일한 방법 으로 배양하였다.

\section{3. 세포독성 시험}

배양된 모유두세포를 96 well plate에 $1 \times 10^{6}$ cell/well로 $100 \mu \mathrm{L}$ 를 분주하여 $37^{\circ} \mathrm{C}, 5 \% \mathrm{CO}_{2}, 12 \mathrm{~h}$ 배양 후, 각 배합비율별로 처리하 였다(Choi et al., 2021). 24 h 재배양 후, EZ-cytox (DoGenBio, Korea)를 $10 \mu \mathrm{L}$ 처리하고 다시 $4 \mathrm{~h}$ 안정화 후, $\mathrm{OD} 450 \mathrm{~nm}$ 에서 흡 광도를 측정하여 세포독성을 확인하였으며, 대조군은 열수 추출에 사용된 멸균수를 사용하였다.

\section{4. 세포증식율 시험}

배양된 모유두세포를 96 well plate에 $1 \times 10^{6}$ cell/well로 $100 \mu \mathrm{L}$ 를 분주하여 $37^{\circ} \mathrm{C}, 5 \% \mathrm{CO}_{2}, 12 \mathrm{~h}$ 배양 후, 각 배합비율별로 처리하 였다(Rastegar et al., 2015; Choi et al., 2021). 24 h 및 48 h 재 배양 후, MTS assay에 따라 MTS시약(CellTiter $96^{\circledR}$ AQueous One Solution Cell Proliferation Assay, PROMEGA, USA)을 $20 \mu \mathrm{L} /$ well 처리하고, 다시 $4 \mathrm{~h}$ 안정화 후, OD $490 \mathrm{~nm}$ 에서 흡광도를 측정하여 세포증식율을 확인하였으며, 대조군 및 추출물의 희석은 세포배양에 사용한 배지를 사용하였다.

\section{5. 항염증 시험}

1) 염증성 사이토카인 억제 시험

세포 배양액 내의 $\mathrm{IL}-6$ 및 TNF- $\alpha$ 를 측정하기 위해 EnzymeLinked Immunosorbent Assay (IL-6, TNF- $\alpha$ ELISA kit, Abnova) 를 수행하였다(Kim et al., 2019b; Shim, 2019; Kim \& Ko, 2020). Raw 264.7 세포를 96 well plate에 $1 \times 10^{5}$ cell/well로 $100 \mu \mathrm{L}$ 를 분 주하여 $37^{\circ} \mathrm{C}, 5 \% \mathrm{CO}_{2}, 12 \mathrm{~h}$ 배양하였다. 배양한 plate에 $0.1 \%$ 황 칠추출물, $1 \%$ 천일염추출물, $5 \%$ 시금치추출물, $1 \%$ 다시마추출 물 및 $\mathrm{OMR}$ 을 각각 처리하고, $1 \mathrm{~h}$ 후 $1 \mu \mathrm{g} / \mathrm{mL}$ lipopolysaccharide (LPS; Sigma Aldrich, USA)를 처리하였다. 처리 후 $12 \mathrm{~h}$ 배양한 세포 배양액을 적절한 농도로 희석 후, capture antibody로 코팅된 96 well plate에 $100 \mu \mathrm{L}$ 씩 첨가하고 상온에서 $2 \mathrm{~h}$ 반응시켰다. 버 퍼로 3 회 세척하고 $100 \mu \mathrm{L}$ detection antibody를 각 well에 처리하 고, $2 \mathrm{~h}$ 동안 상온에서 반응시킨 후 버퍼로 3 회 세척하였다. $100 \mu \mathrm{L}$ 의 streptavidin-HRP solution을 처리하여 $20 \mathrm{~min}$ 동안 상온 암실 에서 반응 후, 버퍼로 3 회 재세척하였다. di(2-ethylhexyl)-2,4,5trimethoxy benzalmalonate (TMB) substrate를 $100 \mu \mathrm{L}$ 처리하여 $30 \mathrm{~min}$ 반응 후, $500 \mu \mathrm{L}$ stop solution을 처리하고, OD $450 \mathrm{~nm}$ 에서 흡광도를 측정하여 $\mathrm{IL}-6$ 및 $\mathrm{TNF}-\alpha$ 를 확인하였고, 대조군은 세포배 양에 사용한 배지를 사용하였다.

\section{2) Western blot analysis}

iNOS 및 $\mathrm{COX}-2$ 의 단백질 발현을 확인하기 위해 western blot analysis를 수행하였다(Park \& Lee, 2005; Park et al., 2019). Raw 264.7 세포를 6 well plate에 $1 \times 10^{5}$ cell/well로 $100 \mu \mathrm{L}$ 를 분주하 여 $37^{\circ} \mathrm{C}, 5 \% \mathrm{CO}_{2}, 12 \mathrm{~h}$ 배양 후, 각 well에 $1 \mu \mathrm{g} / \mathrm{mL} \mathrm{LPS}, 0.1 \%$ 황 칠추출물, $1 \%$ 천일염추출물, $5 \%$ 시금치추출물, $1 \%$ 다시마추출물 및 $\mathrm{OMR}$ 을 각각 처리하고, $24 \mathrm{~h}$ 배양하였다. $\mathrm{PBS}$ 로 세척 후 $100 \mu \mathrm{L}$ 의 lysis buffer [20 mM Tris- HCl (pH7.4), 5 mM EDTA(pH 8.0), $5 \mathrm{mM} \mathrm{Na}_{4} \mathrm{P}_{2} \mathrm{O}_{7}, 10 \mathrm{mM} \mathrm{NaF}, 100 \mathrm{mM}$ Nonidet P-40, $1 \% \mathrm{NaVO}_{4}$, $0.5 \% \mathrm{EZ} \mathrm{Block}$ 를 첨가하고, $1,400 \mathrm{rpm}, 4^{\circ} \mathrm{C}$ 에서 $15 \mathrm{~min}$ 원심 분리 하여 상층액에서 단백질을 추출하였다. 동일한 양의 단백질을 $10 \%$ sodium dodecyl sulfate-polyacrylamide gel electrophoresis (SDSPAGE)로 분리한 후, PVDF membrane에 transfer하였다. 5\% Skim milk로 $2 \mathrm{~h}$ blocking 후, 1 차 항체인 iNOS 및 $\mathrm{COX}-2$ 를 $4{ }^{\circ} \mathrm{C}, 24 \mathrm{~h}$ 반응시켰다. TBST 용액(0.05\% Tween-20)을 이용하여 3회 세척하 고, 2차 항체(1:2,000 dilution, cell signaling technology)를 상온 에서 $60 \mathrm{~min}$ 반응시켰다. TBST 용액으로 다시 3 회 세척하고, ECL plus kit (Biosesang, Korea) 처리 후 단백질 발현 정도를 확인하였다. 표준물질로는 bovine serum albumin (BSA)을 사용하였고, Lowry법 으로 정량하였으며, 대조군은 세포배양에 사용한 배지를 사용하였다.

\section{6. 항균활성 시험}

항균활성은 그람 음성균인 대장균(Escherichia Coli, E. Coli; 
KCTC 1467), 녹농균(Pseudomonas aeruginosa, P. aeruginosa; $\mathrm{KCTC} 2004$ )과 그람 양성균인 황색포도상구균(Staphylococcus aureus, S. aureus; KCTC 1927) 등 총 3종에 대하여 paper disc (Advantec, Japan) 법으로 확인하였다(Table 2). 각 균주는 LuriaBertani (BD Difco, USA) 배지로 $120 \mathrm{rpm}, 37^{\circ} \mathrm{C}, 12 \mathrm{~h}$ 배양하였다. 배양한 균주는 $1 \times 10^{6} \mathrm{cell} / \mathrm{mL}$ 로 희석 후 $100 \mu \mathrm{L}$ 를 $\mathrm{LB}$ 배지에 도말 하고, paper disc에 $0.1 \%$ 황칠추출물, $1 \%$ 천일염추출물, $5 \%$ 시금치 추출물, $1 \%$ 다시마추출물 및 $\mathrm{OMR}$ 을 각각 $40 \mu \mathrm{L}$ 처리 후 $37^{\circ} \mathrm{C}, 12$ $\mathrm{h}$ 배양하여 생육저지환 $(\mathrm{mm})$ 을 측정하였다.

\section{7. 통계 분석}

통계 분석은 GraphPad 프로그램(GraphPad Software, USA)을 이 용하여 평균값 및 표준편차를 산출하였다. 각 군 간의 유의성은 일원 분산분석(one-way analysis of variance, one-way ANOVA)으로 확 인하였고, 모든 값의 차이는 신뢰수준 $95 \%$ ( $p<0.05)$ 로 검증하였다.

\section{Results \& Discussion}

\section{1. 최적 배합비율(OMR)}

이미 앞선 연구에서 황칠, 천일염, 시금치 및 다시마를 $1: 10$ 중량 비로 열수 추출한 각 추출물에서 세포독성, 세포 증식율, 항염증 및
항균활성 등을 수행한 바 있다(Choi et al., 2021). 선행 연구에서 세 포독성과 세포증식율은 황칠추출물 $0.5 \mathrm{mg} / \mathrm{mL}$, 천일염추출물 2 $\mathrm{mg} / \mathrm{mL}$, 시금치추출물 $5 \mathrm{mg} / \mathrm{mL}$, 다시마추출물 $1 \mathrm{mg} / \mathrm{mL}$ 농도 이 내에서 안전성과 유효성을 확인할 수 있었다(Choi et al, , 2021). 이 상의 결과를 토대로 본 연구에서는 보다 안전하고, 유효성이 우수한 최적 배합비율을 찾기 위해 황칠추출물은 $0.1,0.3,0.5$ 비율, 천일염 추출물은 1,2 비율, 시금치추출물은 $1,3,5$ 비율, 다시마추출물은 1 비율로 하여 총 18 개의 배합비율을 선정하였다(Table 1).

\section{2. 세포독성 시험}

선정된 18 개 시료의 배합비율별 모유두세포의 세포독성 시험을 수 행하였다(Figure 1), 특히 천일염추출물의 배합비율이 1 인 경우에 대 체로 세포 생존율이 높게 나타났으며, 황칠추출물과 시금치추출물 의 배합비율이 높을 때에도 세포 생존율이 높은 경향을 나타냈다. 반 면 천일염추출물의 배합비율이 2 인 경우에는 대체로 세포 생존율이 낮게 나타났는데, 이는 천일염의 염분(salt)과 황칠 자체의 독성이 세 포 생존에 영향을 주는 것으로 확인되었다. 총 18 개 시료 중 $8,12-$ $15,17-19$ 등 총 8개 시료에서 80\% 이상의 세포 생존율이 확인되었 다. 선행 연구에서 시금치 열수추출물의 경우 $5 \mathrm{mg} / \mathrm{mL}$ 농도에서 약 $30 \%$ 의 세포독성을 나타내었지만(Choi et al., 2021), 배합비율 12 및 13 의 경우, 세포독성이 낮아진 것으로 보아 배합추출시 시금치의 세 포독성을 줄이는 것으로 판단된다.

Table 1. Mixing ratio (weight ratio) of sea salt, Dendropanax, spinach, and kelp

\begin{tabular}{|c|c|c|c|c|}
\hline \multirow{2}{*}{ Sample name } & \multicolumn{4}{|c|}{ Ratio of mixing $(\mathrm{mg} / \mathrm{mL})$} \\
\hline & Sea salt (Sal.) & Dendropanax (Den.) & Spinach (Spi.) & Kelp (Kel.) \\
\hline 1 & \multicolumn{4}{|c|}{ Control } \\
\hline 2 & 2 & 0.5 & 5 & 1 \\
\hline 3 & 2 & 0.3 & 5 & 1 \\
\hline 4 & 2 & 0.1 & 5 & 1 \\
\hline 5 & 2 & 0.5 & 3 & 1 \\
\hline 6 & 2 & 0.3 & 3 & 1 \\
\hline 7 & 2 & 0.1 & 3 & 1 \\
\hline 8 & 2 & 0.5 & 1 & 1 \\
\hline 9 & 2 & 0.3 & 1 & 1 \\
\hline 10 & 2 & 0.1 & 1 & 1 \\
\hline 11 & 1 & 0.5 & 5 & 1 \\
\hline 12 & 1 & 0.3 & 5 & 1 \\
\hline 13 & 1 & 0.1 & 5 & 1 \\
\hline 14 & 1 & 0.5 & 3 & 1 \\
\hline 15 & 1 & 0.3 & 3 & 1 \\
\hline 16 & 1 & 0.1 & 3 & \\
\hline 17 & 1 & 0.5 & 1 & 1 \\
\hline 18 & 1 & 0.3 & 1 & 1 \\
\hline 19 & 1 & 0.1 & 1 & 1 \\
\hline
\end{tabular}




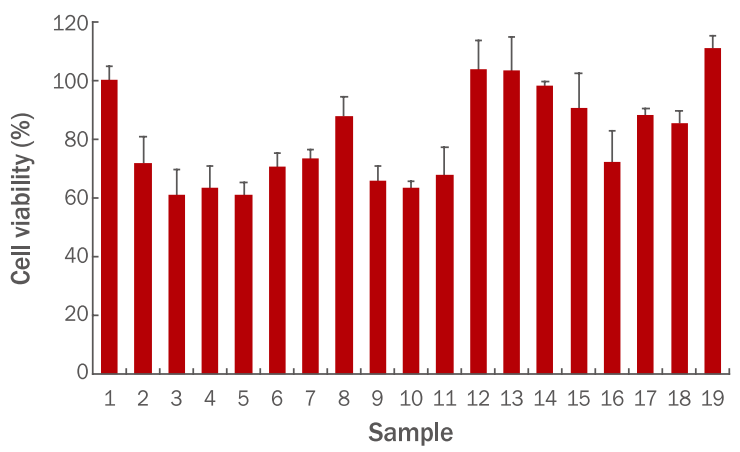

Figure 1. Cytotoxicity according to mixing ratio.

We confirmed 8 mixing ratio extracts that were over $80 \%$. Among them, samples 12,13 , and 19 showed similar results as compared to the control (number 1). Each bar indicates the mean \pm standard deviation of determinations $(n=3)$. We used a one-way ANOVA as our statistical analysis.

\section{3. 세포증식율 시험}

탈모증상 완화 효과를 확인하기 위해 선정된 8개 시료의 모유두 세포의 세포증식율 시험을 수행하였다(Figure 2). 특히 시료 8은 시 료 1 (control)에 비해 약 20\% 세포증식율이 감소하는 경향으로 나타 났고, 나머지 7개 시료들은 세포증식율이 시료 1 (control)에 비해 유 사하거나 증가하는 경향으로 나타났다. 시료 8의 세포증식율이 감소 한 이유는 다른 시료들에 비해 높은 천일염의 높은 염분(salt)이 세 포증식율에 영향을 주는 것으로 확인되었다. 특히 시료 12 는 시료 1 (control)에 비해 약 $30 \%$ 세포증식율이 증가하는 경향으로 나타났으 나, 시간이 $24 \mathrm{~h}$ 에서 $48 \mathrm{~h}$ 으로 증가함에 따라 상대적으로 세포증식 율은 감소하는 경향으로 나타났다. 반면 시료 13은 시료 1 (control) 에 비해 시간에 관계없이 약 $20 \%$ 세포증식율이 증가하는 경향으로 나타났다. 이러한 결과를 토대로 시료 12 이 시료 13 과 차이가 있는 이유는 황칠추출물의 비율이 0.1 에서 보다 0.3 으로 증가하면 시간이 경과됨에 따라 세포증식율에 영향을 주는 것으로 판단되었다. 따라서 $\mathrm{OMR}$ 이 $0.1: 1: 5: 1$ 인 시료 13 에서 세포증식율이 최적인 것으로 확인 되었다(Table 2). OMR 중 시금치 $(5 \mathrm{mg} / \mathrm{mL})$ 와 미역 $(1 \mathrm{mg} / \mathrm{mL})$ 의 비 율은 선행연구에서 확인된 가장 높은 세포증식율을 나타낼 수 있는 농도로 선정되었다(Choi et al., 2021).

\section{4. 항염증 시험}

\section{1) 염증성 사이토카인 억제 시험}

$\mathrm{OMR}$ 에 대한 $\mathrm{IL}-6$ 와 $\mathrm{TNF}-\alpha$ 의 발현 억제 효과를 확인하기 위해 Raw 264.7 세포의 항염증 시험을 수행하였다(Figure 3). Raw 264.7 세포는 LPS $1 \mu \mathrm{g} / \mathrm{mL}$ 의 농도로 처리하였을 때 $\mathrm{IL}-6$ 및 $\mathrm{TNF}-\alpha$ 의 발 현이 증가되는 것으로 확인되었고, LPS 처리 후 대조군에 비해 천일 염추출물 비율 1 과 $\mathrm{OMR}(0.1: 1: 5: 1)$ 에서 $\mathrm{IL}-6$ 의 발현이 감소하였 다(Figure $3 \mathrm{~A}$ ). 반면 황칠추출물 비율 0.1 과 시금치추출물 비율 5 및

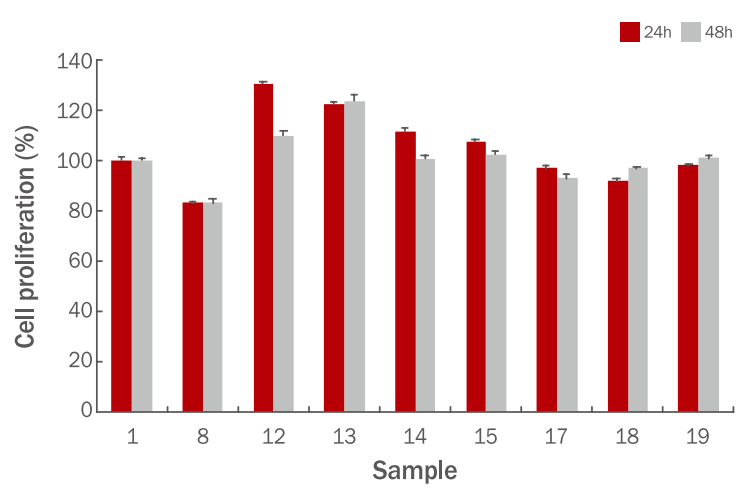

Figure 2. Cell proliferation of the various OMRs in HFDPC cells. We confirmed samples $12,13,14,15$, and 19 that were effective. Among them, sample 13 was the one in which both 24-h and 48-h cell proliferation increase was identified. Each bar indicates the mean \pm standard deviation of determinations $(n=3)$. We used a one-way ANOVA as our statistical analysis. OMR, optimal mixing ratio; HFDFC, human follicle dermal papilla cell.

다시마추출물 비율 1 에서는 모두 대조군에 비해 $\mathrm{IL}-6$ 의 발현이 증가 되었다. 특히 OMR은 각 추출물 농도에서 보다 $\mathrm{IL}-6$ 의 발현을 더 효 율적으로 억제하였다. TNF- $\alpha$ 의 경우 LPS 처리 후 대조군에 비해 다 시마추출물 비율 1 을 제외하고는 모든 처리구에서 다소 감소하는 경 향이 나타났다(Figure $3 \mathrm{~B})$. 따라서 $\mathrm{OMR}(0.1: 1: 5: 1)$ 은 $\mathrm{TNF}-\alpha$ 에서 보다 $\mathrm{IL}-6$ 에서 선택적인 억제 효과가 있고, 단일 추출물 보다 더 높 은 억제 효과가 있기 때문에 향후 $\mathrm{IL}-6$ 에 선택적 항염증 효과를 가진 화장품 원료로서 활용되어질 수 있을 것이다.

\section{2) Western blot analysis}

$\mathrm{iNOS}$ 는 LPS, TNF- $\alpha$ 등과 같은 염증 유발인자 및 암 발생인자 에 의해 발현되며 $\mathrm{NO}$ 생성을 유도하고, $\mathrm{COX}-2$ 의 경우 성장인자, 염 증 유발인자, 산화적 스트레스, 외상, 암 유전자, 사이토카인 등에 의 해 유도되는 효소로서 염증 반응에 관여한다(Park \& Lee, 2005). 상 기 염증성 사이토카인 억제 시험에서 $\mathrm{IL}-6$ 및 $\mathrm{TNF}-\alpha$ 항염증 효과 를 확인한 후, 염증 유발 매개체인 NO 및 PGE2에 대한 염증 억제 효 과를 확인하기 위해 iNOS 및 COX-2 단백질 발현율을 western blot analysis로 확인하였다(Figure 4). 그 결과, iNOS의 발현율은 다시마 추출물 비율 1 과 $\mathrm{OMR}$ 처리 시 LPS를 처리한 대조군에 비해 현저히 감소하는 것으로 확인되었다(Figure $4 \mathrm{~A}$ ), 반면 천일염추출물 비율 1 과 황칠추출물 비율 0.1 에서는 대조군에 비해 다소 증가하는 것으로 확인되었으며, 시금치추출물 비율 5 는 대조군에 비해 차이가 미미한 수준이었다. 또한 $\mathrm{COX}-2$ 단백질 발현율은 LPS를 처리한 대조군에 비해 다시마추출물 비율 1 을 제외한 모든 처리구에서 증가하는 것으 로 확인되었다. 특히, 시금치추출물 비율 5 와 OMR에서 대조군에 비 해 그 발현 정도가 현저히 증가하였다. 따라서 $\mathrm{iNOS}$ 의 경우, OMR이 각 추출물에 비해 현저히 감소하지만, $\mathrm{COX}-2$ 에서는 $\mathrm{OMR}$ 이 각 추 
A

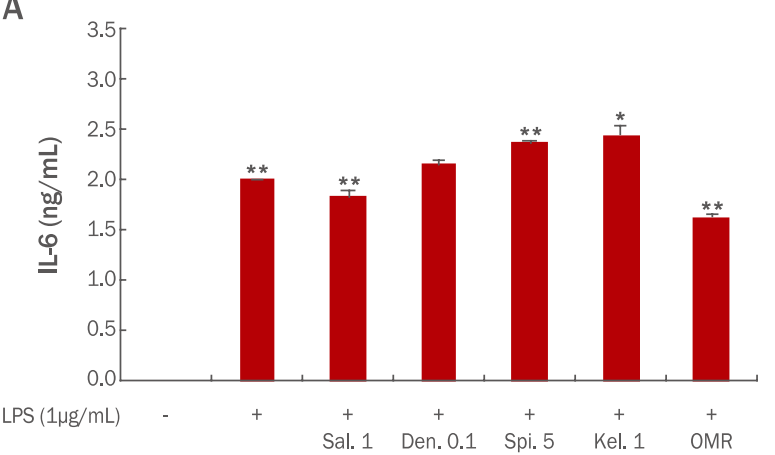

B

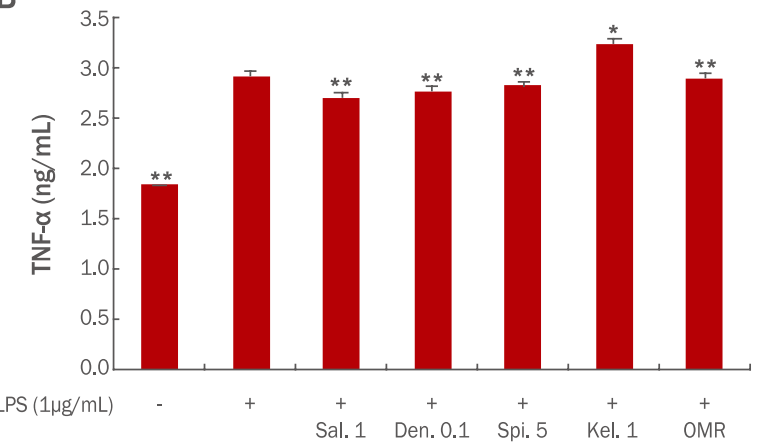

Figure 3. OMR's anti-inflammatory effects on IL-6 and TNF- $\alpha$ production in LPS-activated Raw 264.7 cells.

We identified the anti-inflammatory effects after treating cells with OMR (sample 13) and extracts at each ratio concentration. We observed that the OMR was the most effective on IL- 6 (A). Whereas, in TNF- $\alpha$, all extracts were of little effect (B). Each bar indicates the mean \pm standard deviation of the determinations $(n=3)$. We used a one-way ANOVA $\left({ }^{* *} p<0.01,{ }^{*} p<0.05\right)$ as our statistical analysis. OMR, optimal mixing ratio; LPS, lipopolysaccharide; IL-6, interleukin 6; TNF- $\alpha$, tumor necrosis factor- $\alpha$; Sal.1, sea salt $(1 \mathrm{mg} / \mathrm{mL})$; Spi.5, spinach (5 mg/mL); Den. 0.1, Dendropanax (0.1 mg/mL); Kel. 1, kelp (1 mg/mL).

A

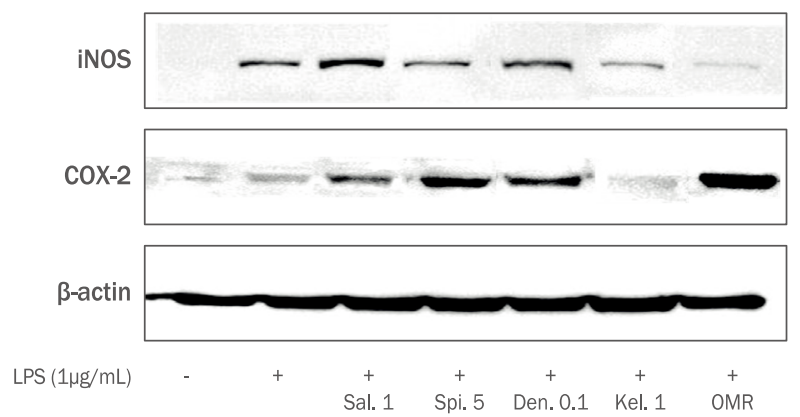

B

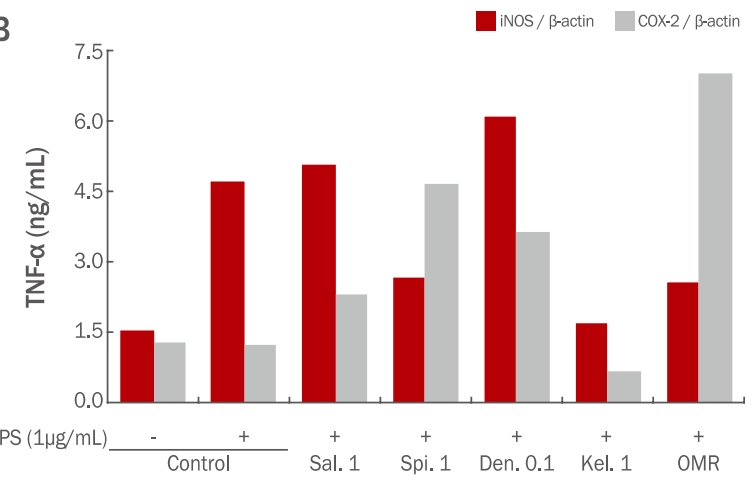

Figure 4. Effect of OMR and each of the extracts on LPS-induced iNOS and COX-2 protein expression in Raw 264.7 cells.

We identified the protein expression after treating cells with OMR and extracts at each ratio concentration (A) and quantified them as a ratio with $\beta$-actin (B). We observed that the OMR selectively decreased iNOS, whereas it had little effect on COX-2 expression. The relative density of each protein band was quantified by ImageJ program. OMR, optimal mixing ratio; LPS, lipopolysaccharide; iNOS, inducible nitric oxide synthase; COX-2, cyclooxygenase-2; Sal.1, sea salt (1 mg/mL); Spi.5, spinach (5 mg/mL); Den. 0.1, Dendropanax (0.1 $\mathrm{mg} / \mathrm{mL}) ;$ Kel. 1, kelp (1 mg/mL).

Table 2. Anti-microbial activity of OMR and each extract on P. aeruginosa, E. coli, and S. aureus

\begin{tabular}{lccc}
\hline \multirow{2}{*}{ Ratio of complex extracts } & \multicolumn{3}{c}{ Inhibition zone diameter $(\mathrm{mm})$} \\
\cline { 2 - 4 } Sal. $(1 \mathrm{mg} / \mathrm{mL})$ & P. aeruginosa & E. coli & S. aureus \\
Den. $(0.1 \mathrm{mg} / \mathrm{mL})$ & 0 & 0 & 0 \\
Spi $(5 \mathrm{mg} / \mathrm{mL})$ & 9 & 0 & 11 \\
Kel. $(1 \mathrm{mg} / \mathrm{mL})$ & 0 & 0 & 0 \\
OMR $(1: 0.1: 5: 1)$ & 0 & 0 & 0 \\
\hline
\end{tabular}

P. aeruginosa, Pseudomonas aeruginosa; E. coli, Escherichia coli, S. aureus, Staphylococcus aureus; Sal., Sea salt; Den., Dendropanax; Spi., Spinach; Kel., Kelp; OMR, optimal mixing ratio. 
출물에 비해 증가하는 결과를 나타냈기 때문에 결과적으로 $\mathrm{OMR}$ 은 iNOS의 발현을 선택적으로 저해하여 항염증 효과를 나타내는 것으 로 판단된다(Figure 4B).

\section{5. 항균활성 시험}

$\mathrm{OMR}$ 의 항균활성을 확인하기 위해 대장균, 녹농균 및 황색포도상 구균 등 3종 미생물에 대한 항균활성 시험을 수행하였다(Table 2). 선 행연구에서 각각의 황칠, 천일염, 다시마 및 미역의 열수추출물 중 황칠추출물에서만 녹농균과 황색포도상구균에서 항균활성을 나타 냄을 확인하였다(Choi et al, , 2021). 마찬가지로, 모든 처리구에서 대장균에 대한 항균활성 효과는 나타나지 않은 반면, 황칠추출물과 $\mathrm{OMR}$ 에서 녹농균과 황색포도상구균에 대한 항균활성 효과가 증가하 는 것으로 나타났다. 특히 녹농균과 황색포도상구균에 대한 항균활 성 효과는 황칠추출물 단독일 때에서 보다 OMR (0.1:1:5:1)일 때 다 소 증가하는 경향으로 나타났다. 따라서 $\mathrm{OMR}$ 이 대장균을 제외한 녹 농균과 포도상구균에 항균활성 효과가 있는 이유는 각 추출물 상호간 시너지 효과에 기인한 것으로 예상된다.

\section{Conclusion}

본 연구는 탈모증상 완화에 도움을 줄 수 있는 기능성 화장품 개발 을 위해 국내산 황칠, 천일염, 시금치 및 다시마 등 추출물의 최적 배 합비율을 찾고, 그 선정된 최적 배합비율에 대한 세포독성, 세포증식 율, 항염증 및 항균활성 효과를 확인하기 위해 수행되었다.

세포독성 시험은 여러 배합비율 중 8 개의 시료에서 $80 \%$ 이상의 세 포 생존율을 확인하였으며, 세포증식율 시험은 앞서 선정된 8 개의 시 료 중 $24 \mathrm{~h}$ 및 $48 \mathrm{~h}$ 모두에서 세포 증식율이 증가한 시료 13 을 최적 배합비율(OMR)로 선정할 수 있었다. 또한, 항염증 시험에서는 선정 된 OMR이 LPS를 처리한 대조군에 비해 $\mathrm{LL}-6$ 와 $\mathrm{iNOS}$ 발현을 선택 적으로 억제하는 것으로 확인되었다.

이상의 결과를 토대로 전남산 황칠추출물, 천일염추출물, 시금치 추출물 및 다시마추출물의 비율이 0.1:1:5:1 비율일 때 탈모증상 완 화에 도움을 줄 수 있는 최적의 기능성 화장품 원료로서 활용 가능할 것이다. 향후 두발용 샴푸 등 시제품에 대한 추가 시험을 통해 더욱 효과적인 제품화가 가능할 것으로 사료된다.

\section{Acknowledgements}

본 연구는 2017년 (재)전남테크노파크에서 주관하는 지역수요맞 춤형 연구개발사업의 일환으로 수행한 연구 결과물임을 밝힙니다.

\section{Author's contribution}

YJC performed data surveys and analysis and wrote the paper with assistance from YGJ. YHC carried out cytotoxicity, cell proliferation and anti-inflammatory experiments. BLK extracted resources, concentrated, freezedried, and supported experiments. MHH mainly performed anti-microbial experiment. HSL supervised the project and YGJ conducted all aspects of experimental design, resources research and data analysis. Finally, YGJ revised the paper.

\section{Author details}

Yeon-je Cho (Researcher), Center of Natural Resources Research, Jeonnam Bioindustry Foundation, 288 Woodland-gil, Anyang-myeon, Jangheunggun, Jeollanam-do 59338, Korea; Byung-Loc Kim (Researcher), Center of Natural Resources Research, Jeonnam Bioindustry Foundation, 288 Woodlandgil, Anyang-myeon, Jangheung-gun, Jeollanamdo 59338, Korea; Yun-Hee Choi(Researcher), Center of Natural Resources Research, Jeonnam Bioindustry Foundation, 288 Woodland-gil, Anyang-myeon, Jangheung-gun, Jeollanam-do 59338, Korea; Min-Hee Han(Researcher), Center of Natural Resources Research, Jeonnam Bioindustry Foundation, 288 Woodland-gil, Anyang-myeon, Jangheung-gun, Jeollanam-do 59338, Korea;Hak-Sung Lee (Director), Center of Natural Resources Research, Jeonnam Bioindustry Foundation, 288 Woodland-gil, Anyang-myeon, Jangheung-gun, Jeollanam-do 59338, Korea; Yong-Gi Jeong (Manager), Center of Natural Resources Research, Jeonnam Bioindustry Foundation, 288 Woodland-gil, Anyangmyeon, Jangheung-gun, Jeollanam-do 59338, Korea.

\section{References}

Choi YH, Cho YJ, Kim BL, Han MH, Lee HS, Jeong YJ. Functional cosmetic effects of Dendropanax, sea salt, and other extracts to alleviate hair loss symptoms. Asian Journal of Beauty and Cosmetology, 19: 1-11, 2021.

Jang IW, Ko WS, Yoon HJ. The latest trends of treatment for alopecia. The Journal of Korean Medicine Ophthalmology and Otolaryngology and Dermatology, 28: 12-28, 2015.

Jung KI, Kim BK, Jeong HK, Oh GH, Kim IK, Kim MY. Antioxidant and anti-inflammatory activities of water and the fermentation liquid of sea tangle (Saccharina japonica). Journal of Life Science, 29: 596-606, 2019. 
Kim DY, Park SJ. Pharmacological therapeutics in androgenetic alopecia. Journal of the Korean Medical Association, 63: 277-285, 2020.

Kim GW, Choi YH, Kim BL, Kim YU, Seong RS, Kim KA, Jeong YG. Determination of anti-oxidative and whitening effects of complex extracts obtained from sprout panax ginseng C.A. Meyer and Cassia nomame (Sieb.) Honda on skin. Asian Journal of Beauty and Cosmetology, 16: 309-320, 2018.

Kim HS, Ko KS. Antioxidant and anti-inflammatory effects of ginseng berry ethanol extracts as a cosmetic ingredient. Asian Journal of Beauty and Cosmetology, 18: 389-397, 2020.

Kim J, Jo A, Lee J. Analysis of the patent trends for natural components related to hair loss. Asia-pacific Journal of Multimedia Services Convergent with Art, Humanities, and Sociology, 9: 375-87. 2019a.

Kim KH, Kim JH, Song HS. The effect of salt in medicine for salt pharmacopuncture. The Acupuncture, 32: 131-145, 2015.

Kim KH, Lee SR, Park HS. Inhibitory effects of three dimensional adipose tissue-derived mesenchymal stem cell conditioned medium on immune response and efficacy evaluation of its cream. Asian Journal of Beauty and Cosmetology, 17: 25-36, 2019b.

Lee SY, Choi EJ, Bae DH, Lee DW, Kim SO. Effects of 1-tetradecanol and $\beta$-sitosterol Isolated from Dendropanax morbifera Lev. on skin whitening, moisturizing and preventing hair loss. Journal of the Society of Cosmetic Scientists of Korea, 41: 73-83, 2015a.

Lee SY, Jang MS, Kim GH. Antioxidant activities and quality characteristics of organic and conventional spinach (Spinacia oleracea). Journal of The Korean Society of Food Culture, 30: 813-817. 2015b.

Lee MS, Joung JS, Park DY. The study about the scalp scaling effect of solar salt and Indigo Pulverata Levis. Asian Journal of Beauty and Cosmetology, 12: 119-125, 2014.

Park EJ, Lee SK. Anti-inflammatory effects of resveratrol and its analogs: COX-2 and iNOS as potential targets. Journal of cancer, 10: 116-123, 2005.

Park JY, Lee JY, Lee DY, Kim HD, Kim GS, Lee SE, Seo KH. Melanogenesis Inhibitory effect of steamed Platycodon grandiflorum on B16F10 cells. Asian Journal of Beauty and Cosmetology, 17: 37-46, 2019.

Pinnell SR, Murad S. Effects of minoxidil on cultured human skin fibroblasts. Dermatologica, 175: 12-18, 1987.

Rastegar H, Ashtiani HA, Aghaei M, Barikbin B, Ehsani A. Herbal extracts induce dermal papilla cell proliferation of human hair follicles. Annals of Dermatology, 27: 667-675, 2015.

Shim JH. Anti-inflammatory effect of zeaxanthin in RAW264.7 cells. Asian Journal of Beauty and Cosmetology, 17: 431439, 2019. 


\section{국문초록}

\section{황칠과 천일염 등의 최적 배합비율에 따른 탈모증상 완화 효과}

조연제, 최윤희, 김병록, 한민희, 이학성, 정용기

(재)전남바이오산업진흥원 천연자원연구센터, 전라남도 장흥군, 한국

목적: 본 연구는 전남산 황칠, 천일염, 시금치 및 다시마 등 추출물의 최적 배합비율(optimal mixing ratio, OMR)을 선정하고, 이 를 이용하여 탈모증상 완화에 도움을 줄 수 있는 기능성 화장품 개발을 위해 수행되었다. 방법: 본 연구팀은 세포독성과 세포증식율 시험을 통해 $\mathrm{OMR}$ 을 선정하였고, 최종 선정된 OMR에 대하여 항염증 및 항균활성 효과를 확인하였다. 결과: 세포독성은 $\mathrm{OMR}$ 이 0.1:1:5:1 일 때 낮은 반면, 세포증식율은 높게 나타났으며, 항염증은 L-6 및 iNOS의 발현을 효과적으로 억제하였다. 또한 항균활 성은 녹농균과 황색포도상구균에서 효과를 보였다. 결론: 본 연구는 탈모증상 완화에 도움을 줄 수 있는 기능성 화장품 개발을 위한 황칠 및 천일염 등에 대한 OMR (0.1:1:5:1)을 선정하였다. 최종 선정한 OMR은 낮은 세포독성과 높은 세포증식율, IL-6 및 iNOS 의 발현 억제 및 항균활성 효과가 확인되었다. 따라서 향후 탈모증상 완화에 도움을 줄 수 있는 기능성 화장품으로서 활용 가능성이 기대된다.

핵심어: 최적 배합비율, 황칠, 천일염, 탈모증상 완화, 기능성 화장품

본 연구는 2017년 (재)전남테크노파크에서 주관하는 지역수요맞춤형 연구개발사업의 일환으로 수행한 연구 결과물임을 밝힙니다.

\section{참고문헌}

김건우, 최윤희, 김병록, 김영욱, 성락선, 한민희, 김경애, 최민주, 정용기. 새싹인삼과 차풀 복합추출물의 피부 항산화 및 미백효과. 아시안뷰티화장품학술지, 18: 309-320, 2018.

김경혜, 이순례, 박현숙. 3 차원(3D) 지방조직유래 간엽줄기세포 조건화 배지의 면역반응 억제 능력과 이를 함유한 크림 타

입 화장품의 유효성 평가. 아시안뷰티화장품학술지, 17: 25-36, 2019.

김기현, 김지화, 송호섭. 염약침을 위한 소금의 의학적 효용. 대한침구의학회지, $32: 131-145,2015$.

김도영, 박수진. 안드로겐탈모증의 약물치료. 대한의사협회지, 63: 277-285, 2020.

김정원, 조아현, 이정현. 탈모 관련 천연물의 특허 동향 분석. 예술인문사회융합 멀티미디어논문지, 9: 375-387, 2019.

김현숙, 고경숙. 인삼열매 에탄올 추출물의 화장품 소재로서 항산화, 항염 효과. 아시안뷰티화장품학술지, 18: 389-397,

2020.

박은정, 이상국. Resveratrol 및 그 유도체의 항염증 작용: 새로운 COX-2 및 iNOS 저해제. 대한암예방학회지, 10:

116-123, 2005.

박정용, 이지연, 이대영, 김형돈, 김금숙, 이승은, 서경혜. $\mathrm{B} 16 \mathrm{~F} 10$ 세포에서 증숙도라지 추출물의 멜라닌 생성 억제 효과. 아시안뷰티화장품학술지, 17: 37-46, 2019.

심중현. 제아잔틴에 의한 AW264.7 세포에서의 항염효과. 아시안뷰티화장품학술지, 17: 431-439, 2019.

이미선, 정지선, 박도영. 천일염과 청대를 활용한 두피스케일링 효능에 관한 연구. 아시안뷰티화장품학술지, 12: 119125, 2014.

이선영, 최은진, 배동혁, 이동욱, 김선오. 미백, 보습 및 탈모방지에 대한 황칠나무 (Dendropanax modifera Lev.)에서 분 리한 1-tetradecanol, $\beta$-sitosterol의 효과. 대한화장품학회지, 41: 73-83, 2015.

이신영, 장민선, 김건희. 유기농 및 일반재배 시금치의 이화학적 특성 및 항산화 활성. 한국식생활문화학회지, $30: 813-$ 817, 2015. 
장인욱, 고우신, 윤화정. 탈모 치료에 관한 최신 동향. 한방안이비인후피부과학회지, 28: 12-28, 2015.

정경임, 김보경, 강정현, 오근혜, 김인경, 김미향. 다시마 물 추출액과 발효액의 항산화 및 항염증 활성. 생명과학회지, 29: 596-606, 2019.

최윤희, 조연제, 김병록, 한민희, 이학성, 정용기. 황칠과 천일염 등을 이용한 탈모증상 완화 화장품 소재개발. 아시안뷰티 화장품학술지, 19: 1-11, 2021. 


\section{中文摘要}

\section{石竹、海盐和其他提取物的最佳混合比例对缓解脱发症状的影响}

趙娟悌，崔允姬，金炳鹿，韓㟲熙，李學成，鄭容琦

(财) 全南生物产业振兴院天然资源研究中心，全罗南道长兴郡，韩国

目的: 该研究旨在通过选择全南黄七、海盐、菠荣和海带等提取物的最佳混合比例 (OMR) 来开发有助于缓解脱 发症状的功能性化妆品。方法: 通过细胞毒性和细胞增殖试验确定了 OMR, 并证实了最终选定的OMR的抗炎和 抗微生物作用。结果: OMR为0.1:1:5:1时，细胞毒性低，但细胞增殖高，抗炎活性有效抑制IL-6和iNOS的表达。 抗微生物活性检测结果显示对铜绿假单胞菌和金黄色葡萄球菌有影响。结论: 本研究选择 OMR (1:0.1:5:1) 开发 有助于缓解脱发症状的功能性化妆品。OMR的最终选择证实了低细胞毒性、高细胞增殖、抑制 IL-6和iNOS 的 表达以及抗微生物活性。因此，它有望在未来成为一种有助于缓解脱发症状的功能性化妆品。

关键词: 最佳混合比例, 丹参, 海盐, 脱发症状, 功能性化妆品 